\title{
Topically Applied Diterpenoids from Egletes viscosa (Asteraceae) Attenuate the Dermal Inflammation in Mouse Ear Induced by Tetradecanoylphorbol 13-Acetate- and Oxazolone
}

\author{
Iana Bantim Felício CAlou, ${ }^{a}$ Daniel Italo Maia Sousa, ${ }^{a}$ Geanne Matos de Andrade Cunha, ${ }^{a}$ \\ Gerly Anne de Castro Brito, ${ }^{b}$ Edilberto Rocha SilveIrA, ${ }^{c}$ Vietla Satyanarayana RAO, ${ }^{a}$ and \\ Flávia Almeida SANTOS $*, a$ \\ ${ }^{a}$ Department of Physiology and Pharmacology, Faculty of Medicine, Federal University of Ceará; ${ }^{b}$ Department of \\ Morphology, Federal University of Ceará; Rua Cel Nunes de Melo, 1127, Porangabussu POB-3157, 60430-270 Fortaleza, \\ Ceará, Brazil: and ${ }^{c}$ Department of Organic and Inorganic Chemistry, Federal University of Ceará; 60451-970 Fortaleza, \\ Ceará, Brazil. $\quad$ Received November 22, 2007; accepted May 16, 2008; published online May 30, 2008
}

\begin{abstract}
The diterpene compounds, centipedic acid (CA) and 12-acetoxyhawtriwaic acid lactone (AHAL, tanabalin) isolated from the flower buds of Egletes viscosa Less. (Asteraceae) were evaluated on acute and chronic models of mouse ear dermatitis. A single topical application of CA $(0.125 ; 0.25$ and $0.5 \mathrm{mg} / \mathrm{ear})$ or AHAL $(0.125,0.25$, $0.5 \mathrm{mg} / \mathrm{ear}$ ) immediately before 12-O-tetradecanoylphorbol-13-acetate (TPA, $2.5 \mu \mathrm{g} / \mathrm{ear}$ ) caused a dose-related significant inhibition of ear inflammatory edema and influx of polymorphonuclear cells, as evidenced by a decrease in ear thickness and reduced myeloperoxidase (MPO) activity and tumor necrosis factor- $\alpha$ (TNF- $\alpha$ ) in ear tissue homogenates. The maximal obtained inhibition for both ear edema and neutrophil influx were almost similar to that of topically applied dexamethasone $(0.05 \mathrm{mg} / \mathrm{ear})$. The extent of inhibitions for the respective treatments of CA $(0.5 \mathrm{mg} / \mathrm{ear})$, AHAL $(0.5 \mathrm{mg} / \mathrm{ear})$, or dexamethasone $(0.05 \mathrm{mg} / \mathrm{ear})$ were in the order $\mathrm{of} 63 \%, 61 \%$ and $81 \%$ for the ear edema, and $90 \%, 95 \%$ and $95 \%$ for the neutrophil influx. Also, at similar doses, both diterpenes and dexamethasone effectively inhibited the delayed-type hypersensitivity reaction induced by repeated topical application of $1 \%$ oxazolone (OXA, $20 \mu \mathrm{l} / \mathrm{ear}$ ), as evidenced by significant decreases in ear thickness and interferon- $\gamma(\mathrm{INF}-\gamma)$ levels in ear tissue. Histopathological analysis revealed a marked decrease in epidermal hyperplasia and neutrophil infiltration in animals pretreated with CA or AHAL, in a manner similar to dexamethasone. These data provide evidence for the anti-dermatitis effect of Egletes viscosa diterpenes, by mechanisms that involve a reduced neutrophil influx and decreased production of inflammatory cytokines, TNF- $\alpha$ and IFN- $\gamma$.
\end{abstract}

Key words Egletes viscosa; diterpene; experimental dermatitis; anti-inflammatory activity

Over the past three decades, the prevalence of atopic dermatitis and allergic or irritant contact dermatitis has been increasing significantly in the general population, causing considerable economic costs and decreased quality of life. ${ }^{1-3)}$ Topical corticosteroids have been the first-choice therapy for treatment of these inflammatory skin diseases such as eczema, atopic and seborrheic dermatitis, and psoriasis. While effective in many patients, this form of therapy carry the concern of local and systemic adverse effects and may induce skin atrophy, especially after long-term use. ${ }^{4,5)}$ In contrast to topical corticosteroids, the more recently introduced calcineurin inhibitors like tacrolimus and pimecrolimus do not induce skin atrophy, even after long-term use but may induce adverse effects such as burning, erythema and pruritus and are contraindicated in patients younger than two years or in those who are immunosuppressed. ${ }^{6,7)}$ Thus, the available drugs, although have efficacy they are associated with adverse effects and therefore the development of new and safe anti-inflammatory topical agents for the treatment of dermatitis is needed.

Studies reveal that a large percentage of patients use some form of complementary and alternative medicine for the treatment of atopic and contact dermatitis, which include herbal remedies. ${ }^{8-10)}$ In the recent past, several diterpene compounds of plant origin such as abietic acid from Pimenta racemosa var. grissea, hypoestoxide from Hypoestes rosea and marrubiin from Marrubium vulgare were shown to be effective in the mouse model of ear edema induced by several phlogestogens like histamine, bradykinin, capsaicin, prostaglandin $\mathrm{E}_{2}$, Croton oil, TPA (12-O-tetradecanoylphorbol 13acetate) or oxazolone. ${ }^{1-13)}$ Centipedic acid (CA) and 12acetoxy-hawtriwaic acid lactone (AHAL, Tanabalin) are the naturally occurring diterpenes isolated from the aerial parts of Egletes viscosa L. (Asteraceae), a traditional medicinal plant. ${ }^{14)}$ Previously we reported on the gastroprotective and antinociceptive properties of these diterpenes as well as an anti-edematogenic activity of tanabolin against ear edema induced by capsaicin. ${ }^{15,16)}$ However, the anti-inflammatory efficacy of these two diterpene compounds was not tested in the models of ear edema induced by either TPA or oxazolone, the most commonly used ones for analysing the agents effective against contact or atopic dermatitis. ${ }^{17,18)}$ Thus as a part of our continuation study, we describe here for the first time the anti-dermatitis effects of these two natural diterpenes from Egletes viscosa using the experimental models of acute and chronic dermatitis induced by TPA and oxazolone, respectively, in the mouse ear.

\section{MATERIALS AND METHODS}

Plant Material and Isolation of Diterpenoids The aerial parts $(2.5 \mathrm{~kg})$ of Egletes viscosa Less. (Asteraceae) were collected from the experimental plantation pertaining to the Department of Agronomy of this University, after its authentication and the voucher specimen (\#16327) was retained in Prisco Bezerra Herbarium of the same University. Centipedic 


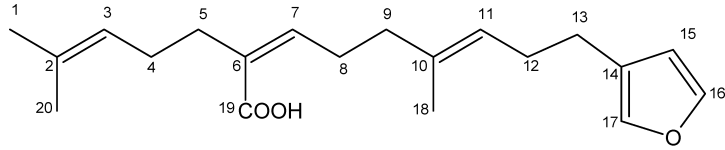

A

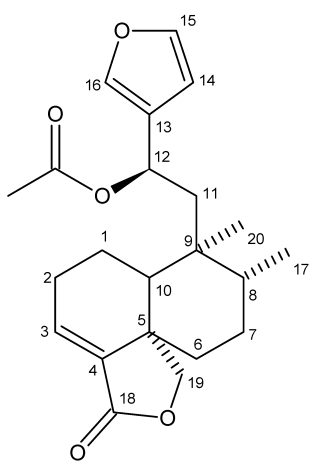

B

Fig. 1. Chemical Structure of Centipedic Acid (A) and 12-Acetoxyhawtriwaic Acid Lactone (Tanabalin) (B)

acid (CA) and 12-acetoxy-hawtriwaic acid lactone (AHAL) were extracted and isolated from the dried plant material as per procedures described ealier ${ }^{14)}$ (Figs. 1A, B). For experiments, CA and AHAL were suspended in aqueous Tween 80 solution (2\%) and control groups were treated with this vehicle in a similar volume as for test groups.

Chemicals and Drugs The chemicals and drugs used in the study were the 12-O-tetradecanoylphorbol-acetate (TPA), oxazolone, dexamethasone, hexadecyltrimethylammonium bromide, $O$-dianisidine dihydrochloride, hydrogen peroxide, formaldehyde, Tween 80 , Tween 20, eosin, hematoxylin were purchased from Sigma Chemical Co. (St. Louis, MO, U.S.A.). TPA was dissolved in acetone. Oxazolone was dissolved in absolute ethanol or in a mixture of acetone and olive oil $(4: 1)$. Dexamethasone was dissolved in saline.

Animals Experiments were performed on male Swiss albino mice $(20-25 \mathrm{~g})$ obtained from the Central Animal House of this University and the Institutional Animal Care and Use Committee approved the experimental protocols, which were in accordance with the guidelines of National Institute of Health, Bethseda, U.S.A.

TPA-Induced Ear Edema An edema was induced on the right ear by topical application of $2.5 \mu \mathrm{g} /$ ear of TPA dissolved in $10 \mu \mathrm{l}$ of acetone. Ear thickness was measured using an electronic caliper YT 202 (Yato eletronics Co., Ltd., China) before TPA application and $4 \mathrm{~h}$ after, and the edema expressed as the increase in ear thickness due to skin inflammation. ${ }^{19,20)}$ Vehicle ( $2 \%$ Tween 80 in water), CA (0.125; $0.25,0.50 \mathrm{mg} / \mathrm{ear})$, AHAL $(0.125 ; 0.25,0.50 \mathrm{mg} / \mathrm{ear})$ or dexamethasone $(0.05 \mathrm{mg} / \mathrm{ear})$ were applied topically in a volume of $20 \mu \mathrm{l}$ to both sides of the ear immediately before to TPA.

Oxazolone-Induced Contact Dermatitis Contact dermatitis was induced in mouse ear according to a previously described method. ${ }^{21,22)}$ Groups of mice $(n=8)$ were first sensitized by application of $100 \mu \mathrm{l}$ of $1.5 \%$ oxazolone in ethanol to the abdomen. Then a total of $20 \mu \mathrm{l}$ of $1 \%$ oxazolone in a mixture of acetone and olive oil (4:1) was applied to both sides of the mouse ear, once in $3 \mathrm{~d}$ starting from day- 7 after sensitization till the day-19. Ear thickness was measured using an electronic caliper YT 202 (Yato Eletronics Co., Ltd., China) $72 \mathrm{~h}$ after each application of the oxazolone. The vehicle ( $2 \%$ Tween 80 in water), CA (0.125;0.25, $0.50 \mathrm{mg} / \mathrm{ear})$, AHAL $(0.125 ; 0.25,0.50 \mathrm{mg} / \mathrm{ear})$ or dexamethasone $(0.5 \mathrm{mg} / \mathrm{ear})$ were topically applied in a volume of $20 \mu \mathrm{l}$ to both sides of the ear $30 \mathrm{~min}$ before and $3 \mathrm{~h}$ after each application of oxazolone.

Myeloperoxidase (MPO) Assay The myeloperoxidase activity in the ear tissue was assessed $4 \mathrm{~h}$ after TPA. ${ }^{23)}$ Ear tissue $(50 \mathrm{mg})$ was minced and homogenized in $1 \mathrm{ml}$ of $50 \mathrm{~mm}$ phosphate-buffered saline (PBS) pH 6.0, containing $0.5 \%$ hexadecyltrimethylammonium bromide (HETAB). The homogenate was subjected to three cycles of freezing $\left(-30^{\circ} \mathrm{C}\right)$ and thawing $\left(37^{\circ} \mathrm{C}\right)$ and brief periods $(15 \mathrm{~s})$ of sonication and after which they were centrifuged at $12000 \times \boldsymbol{g}$ for $15 \mathrm{~min}$ at $4{ }^{\circ} \mathrm{C}$. The supernatant $(0.1 \mathrm{ml})$ was mixed with $2.9 \mathrm{ml}$ of $50 \mathrm{~mm}$ phosphate buffer, $\mathrm{pH} 6.0$, containing $0.167 \mathrm{mg} / \mathrm{ml} o$-dianisidine dihydrochloride and $0.0005 \%$ hydrogen peroxide. The change in absorbance at $470 \mathrm{~nm}$ was then measured for 5 min using a Beckman spectrophotometer (Beckman DU 640B).

Measurement of Tumor Necrosis Factor- $\alpha$ (TNF- $\alpha$ ) The TNF- $\alpha$ in mouse ear tissue was assessed $4 \mathrm{~h}$ after TPA. ${ }^{18)}$ Ears were excised from the animal groups treated with vehicle, CA $(0.5 \mathrm{mg} / \mathrm{ear})$, AHAL $(0.5 \mathrm{mg} / \mathrm{ear})$ or dexamethasone $(0.05 \mathrm{mg} / \mathrm{ear})$, and homogeneized in $50 \mathrm{~mm}$ Tris-HCl buffer ( $\mathrm{pH} 7.5$ ) with $1 \mathrm{~mm}$ EDTA, and their homogenates was incubed on ice for $15 \mathrm{~min}$ in the presence of $0.1 \%$ Triton $\mathrm{X}-100$. The homogenates were centrifuged at $10000 \times \boldsymbol{g}$ for $10 \mathrm{~min}$. TNF- $\alpha$ in the supernatant was measured by ELISA using the commercial kit for TNF- $\alpha$ (Quantikine $^{\circledR}$, R\&D Systems, Minneapolis, U.S.A.). The assay was performed according to the manufacturer's instructions.

Measurement of Interferon- $\boldsymbol{\gamma}($ IFN- $\boldsymbol{\gamma}$ ) The IFN- $\boldsymbol{\gamma}$ in mouse ear tissue was assessed $6 \mathrm{~h}$ after the last application of oxazolone. ${ }^{24)}$ Ears were excised from the animal groups treated with vehicle, CA $(0.5 \mathrm{mg} / \mathrm{ear})$, AHAL $(0.5 \mathrm{mg} / \mathrm{ear})$ or dexamethasone $(0.05 \mathrm{mg} / \mathrm{ear})$, and homogeneized with $1 \mathrm{ml}$ of $0.1 \%$ Tween 20 in phosphate-buffered saline (PBS; $\mathrm{pH}$ 7.4). Samples were frozen at $-30^{\circ} \mathrm{C}$ for $30 \mathrm{~min}$, thawed in a $37^{\circ} \mathrm{C}$ water bath for $15 \mathrm{~min}$ with the freezing and thawing procedure repeated once, then were sonicated for $15 \mathrm{~s}$ and centrifuged for $5 \mathrm{~min}$ at $13000 \times \boldsymbol{g}$. The supernatants were collected and kept at $-30^{\circ} \mathrm{C}$ until measurement of cytokines. IFN- $\gamma$ levels were determined using the commercial kit of ELISA (Quantikine ${ }^{\circledR}$ ) from R\&D Systems (Minneapolis, U.S.A.). The assay was performed according to the manufacturer's instructions.

Histopathological Study Mouse ears were excised $4 \mathrm{~h}$ after TPA administration and $6 \mathrm{~h}$ after the last application of oxazolone and fixed in $10 \%$ buffered formalin solution, embedded in paraffin by standard methods, cut into $5 \mu \mathrm{m}$ sections, stained with hematoxylin-eosin, and then assessed under light microscopy.

Statistical Analysis The results are expressed as mean \pm S.E.M. from 8 mice per group. For statistical analysis, ANOVA followed by Student Newman Kuel's post hoc test was used. A $p<0.05$ was considered statistically significant. 


\section{RESULTS}

TPA $(2.5 \mu \mathrm{g} /$ ear $)$ in the mouse ear induced an edematogenic response as evidenced by a marked increase in ear thickness and as well as a marked increase in MPO activity, a marker of neutrophil influx at $4 \mathrm{~h}$ following its topical application (Figs. 2A, B). Animal groups that received topical pre-treatments with either CA or AHAL $(0.125 ; 0.25,0.5$ $\mathrm{mg} /$ ear) showed significantly less ear edema to the extent of $33 \%, 50 \%, 63 \%$, and $45 \%, 55 \%$ and $61 \%$, respectively (Fig. $2 \mathrm{~A})$. MPO activity was also markedly reduced in animal groups that received either of these diterpenes and the inhibitions were in the order of $76 \%, 85 \%, 90 \%$ for $\mathrm{CA}$, and $81 \%$, $86 \%$ and $95 \%$ for AHAL, respectively (Fig. 2B). The corticosteroid dexamethasone $(0.05 \mathrm{mg} /$ ear $)$ also significantly suppressed the ear edema and MPO activity by $81 \%$ and $95 \%$, respectively. TPA significantly enhanced the TNF- $\alpha$ in the ear tissue of vehicle-treated mice (Fig. 2C). The TPAassociated increase in TNF- $\alpha$ levels were significantly low in animal groups treated with CA $(0.5 \mathrm{mg} / \mathrm{ear})$, AHAL $(0.5$ $\mathrm{mg} / \mathrm{ear})$ or dexamethasone $(0.05 \mathrm{mg} / \mathrm{ear})$.

In the oxazolone challenged group, the ear thickness significantly increased from day 4 onwards and stayed all throughout the experimental period, an indication of chronic dermatitis. CA $(0.25,0.5 \mathrm{mg} / \mathrm{ear} / \mathrm{d})$, AHAL $(0.5 \mathrm{mg} / \mathrm{ear} / \mathrm{d})$ and dexamethasone $(0.05 \mathrm{mg} / \mathrm{ear} / \mathrm{d})$ significantly suppressed the oxazolone-induced increase in ear thickness (Figs. 3A,
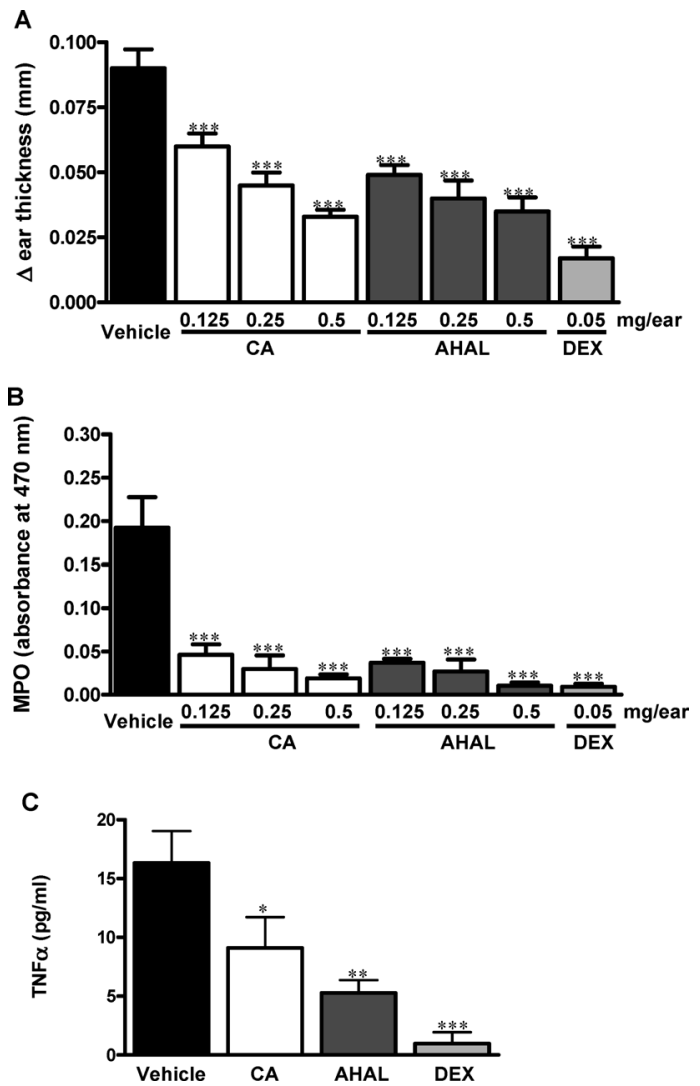

Fig. 2. Effect of Topically Applied Centipedic Acid (CA), 12-Acetoxyhawtriwaic Acid Lactone (AHAL), and Dexamethasone (DEX) on TPAInduced Ear Edema (A), Myeloperoxidase Activity (B) and on the Levels of TNF- $\alpha(\mathrm{C})$ in Supernatants of Homogenates from TPA-Treated Mice Ears

The data are expressed as mean \pm S.E.M. for 8 animals. $* p<0.05 ; * * p<0.01$ $* * * p<0.001$ compared with vehicle (ANOVA and Student Newman Keul's test).
B). Oxazolone significantly enhanced the interferon- $\gamma$ in the ear tissue of vehicle-treated mice (Fig. 3C). The oxazoloneassociated increase in IFN- $\gamma$ levels were significantly low in animal groups treated with CA $(0.5 \mathrm{mg} / \mathrm{ear})$, AHAL $(0.5$ $\mathrm{mg} / \mathrm{ear})$ or dexamethasone $(0.05 \mathrm{mg} / \mathrm{ear})$.

Histological analysis of representative mouse ear $4 \mathrm{~h}$ after application of TPA $(2.5 \mu \mathrm{g} / \mathrm{ear})$ showed intense dermal edema and inflammatory cell infiltration (Fig. 4B), compared to the one treated with vehicle (Fig. 4A). Figure 4D details the TPA-induced intense dermal edema and much cell infiltration with mononuclear and polimorphonuclear cells as compared with vehicle treatment (Fig. 4D). These events were markedly reduced in ear tissues of animal groups treated with dexamethasone $(0.05 \mathrm{mg} / \mathrm{ear}), \mathrm{CA}(0.5 \mathrm{mg} / \mathrm{ear})$, or AHAL $(0.5 \mathrm{mg} / \mathrm{ear})$ (Figs. 4E, F, G, respectively). Repeated applications of oxazolone $(1 \%, 20 \mu \mathrm{l} /$ ear $)$ induced an intense dermal edema, hyperplasia, and inflammatory cell infiltration with mononuclear and polimorphonuclear cells in ear tissues of vehicle-treated controls (Fig. 5A). Treatment with dexamethasone $(0.05 \mathrm{mg} /$ ear $)$ prevented both dermal edema and the inflammatory cell infiltration (Fig. 5B). While CA $(0.5 \mathrm{mg} /$ ear $)$ reduced prominently the cell infiltration, its
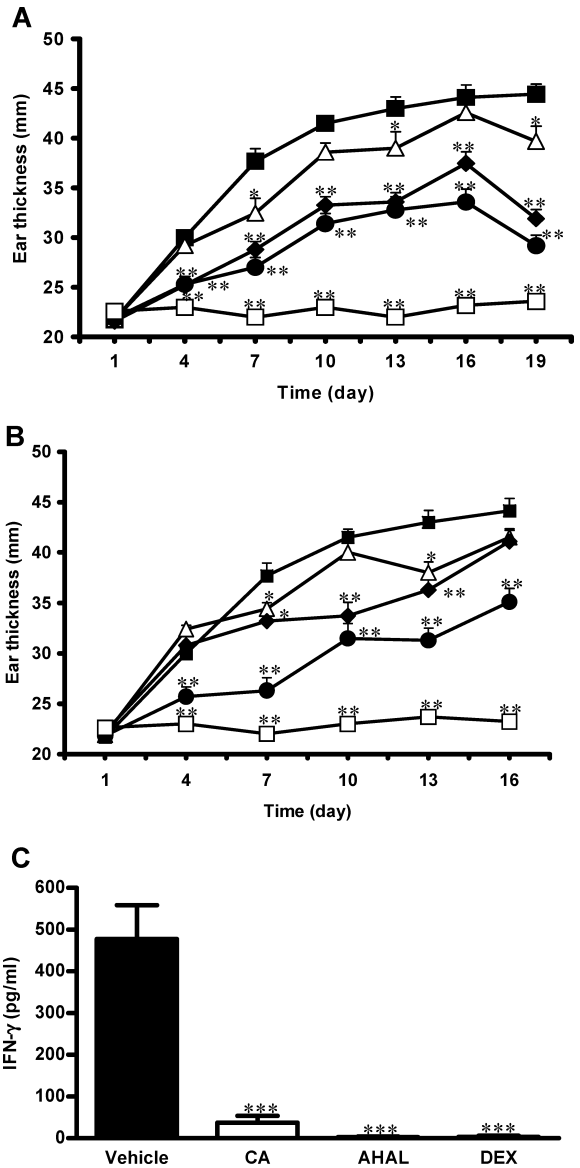

Fig. 3. Effect of Topically Applied (A) Centipedic Acid (CA) and Dexamethasone and (B) 12-Acetoxy-hawtriwaic Acid Lactone (AHAL) and Dexamethasone on Oxazolone-Induced Contact-Delayed Hypersensitivity Mouse Ear Edema

In $(\mathrm{C})$ shows the effect of topically applied centipedic acid (CA), 12-acetoxy-hawtriwaic acid lactone (AHAL), and dexamethasone (DEX) on the levels of INF- $\gamma$ in ear tissue homegenates. Each symbol and vertical bar represents the mean \pm S.E.M. for 8

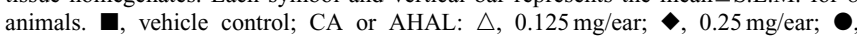
$0.5 \mathrm{mg} / \mathrm{ear} ; \square$, dexamethasone $0.05 \mathrm{mg} / \mathrm{ear} . * p<0.05$; $* *<<0.01 ; * * * p<0.001 \mathrm{com}-$ pared with vehicle (ANOVA and Student Newman Keul's test). 

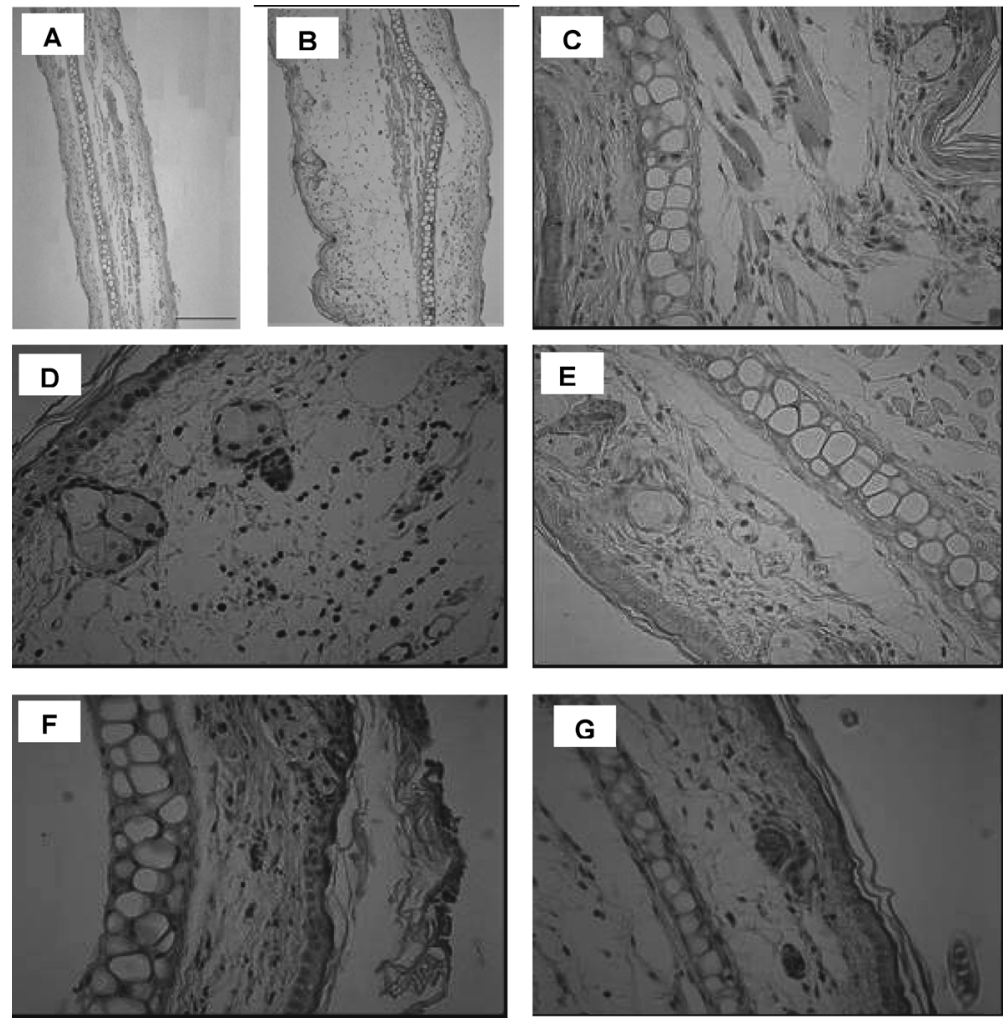

Fig. 4. Histological Analysis of Representative Mouse Ear

$(\mathrm{A}, \mathrm{B} \times 100)(\mathrm{A})$ vehicle-treated control; (B) TPA treated $(2.5 \mu \mathrm{g} /$ ear $)$ showing intense dermal edema, inflammatory cell infiltration. $(\mathrm{C}, \mathrm{D}, \mathrm{E}, \mathrm{F}, \mathrm{G} \times 400)(\mathrm{C}) \mathrm{Details}$ of vehicletreated control; (D) TPA treated $(2.5 \mu \mathrm{g} /$ ear) showing intense dermal edema, inflammatory cell infiltration with presence of mononuclear and polimorphonuclear cells; (E) Dexamethasone $(0.05 \mathrm{mg} / \mathrm{ear})+\mathrm{TPA}$; (F) CA $(0.5 \mathrm{mg} / \mathrm{ear})+\mathrm{TPA}$; (G) AHAL $(0.5 \mathrm{mg} / \mathrm{ear})+\mathrm{TPA}$. The treatment with dexamethasone, centipedic acid, and AHAL prevented the dermal edema and the inflammatory cell infiltration. Hematoxylin-eosin.
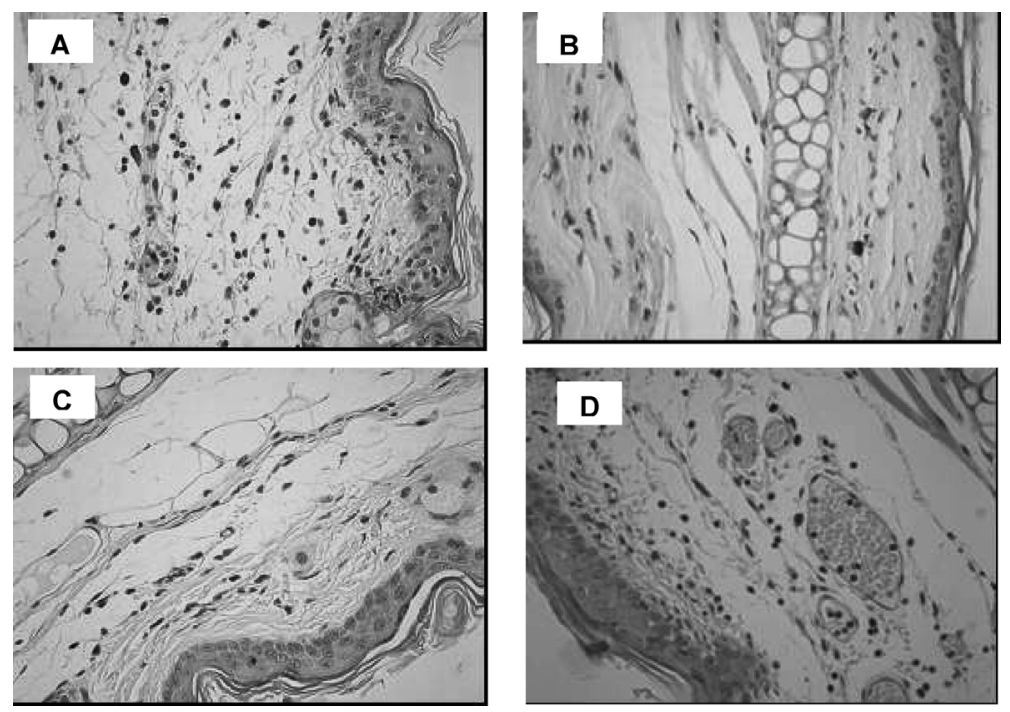

Fig. 5. Histological Analysis of Representative Mouse Ear

(A) Oxazolone (OXA) treated (2.5 $\mu \mathrm{g} /$ ear) showing intense dermal edema, inflammatory cell infiltration with presence of mononuclear and polimorphonuclear cells; (B) Dexamethasone $(0.05 \mathrm{mg} / \mathrm{ear})+\mathrm{OXA}$; (C) CA $(0.5 \mathrm{mg} / \mathrm{ear})+\mathrm{OXA}$; (D) AHAL ( $0.5 \mathrm{mg} / \mathrm{ear})+\mathrm{OXA}$. The treatment with dexamethasone and centipedic acid prevented the dermal edema and the inflammatory cell infiltration whereas AHAL only partially reduced these histological alterations. (Hematoxylin-eosin, $\times 400)$

anti-edema effect was partial and inferior to that of dexamethasone (Fig. 5C). AHAL treatment resulted in only smaller reductions of dermal edema and inflammatory cell infiltration (Fig. 5D).

\section{DISCUSSION}

The results of this investigation provide evidence that the diterpenes centipedic acid (CA) and 12-acetoxy-hawtriwaic acid lactone (AHAL) from Egletes viscosa are topically active in the attenuation of acute dermatitis induced by $12-O-$ tetradecanoylphorbol-13-acetate (TPA) or chronic dermatitis- 
induced by oxazolone. Both compounds $(0.125 ; 0.25,0.5$ $\mathrm{mg}$ /ear) caused a dose-dependent suppression of TPA-associated inflammatory edema, polymorphonuclear leukocyte migration, and the increase in tissue levels of TNF- $\alpha$, in a manner similar to dexamethasone, the reference anti-inflammatory drug. Topical application of TPA, the well-characterized protein kinase $\mathrm{C}$ activator and tumor promoter, is a valid model to screen compounds effective for potential topical antiinflammatory therapy. A single aplication of TPA induces oxidative stress, cutaneous inflammation and epidermal hyperplasia due to enhanced keratinocyte proliferation. TPA induces TNF- $\alpha$ production and the formation of LTB4 with a resultant increase in vascular permeability and neutrophil influx. ${ }^{18)}$ Myeloperoxidase (MPO) is an enzyme found in neutrophils, which is commonly used as an index of granulocyte infiltration, and its inhibition is indicative of an antiinflammatory action. ${ }^{23)}$ Therefore in characterizing the topical antiinflammatory potential of diterpenes under investigation, we examined their effects on TPA-associated increase in TNF- $\alpha$ and on MPO activity in mouse ear homogenates. The topical application of CA and AHAL, similar to the antiinflammatory drug dexamethasone, resulted in marked inhibition of TNF- $\alpha$ and MPO activity, and consequently the edema formation and migration of polymorphonuclear leukocytes induced by TPA. Our histological analysis of the ear tissue clearly confirmed that the diterpenes and dexamethasone inhibited the influx of polymorphonuclear cells to the mouse ear skin following TPA application.

The mouse ear edema test allows not only to identify the potential allergens on the basis of challenge-induced increases in ear thickness in sensitized animals, but also undertake a subsequent study on potential inhibitory agents. ${ }^{25)}$ The inhibition of this dermal reaction can be expressed as the decrease in ear edema or ear thickness as compared to the control group. In the present study oxazolone applied to sensitized mice induced an increase in ear thickness that reached the maximum level, 16 to $19 \mathrm{~d}$ after sensitization. The contact dermatitis induced by oxazolone was associated with a concomitant increase in tissue levels of IFN- $\gamma^{22}$ ) Topical application of CA and AHAL markedly suppressed the ear thickening and epidermal hyperplasia as well as the increase in IFN- $\gamma$, suggesting their usefulness in skin diseases such as psoriasis wherein IFN- $\gamma$ plays a crucial role. However, while the effects of diterpenes on IFN- $\gamma$ production are equivalent to dexamethasone, the antiedema effect of diterpenes under investigation showed a decline of efficacy with time, more so with AHAL. In this context, studies of Saulnier et al. have shown that in mice with a targeted disruption of the IFN- $\gamma$ receptor, the cutaneous edema is IFN- $\gamma$-independent. ${ }^{26)} \mathrm{Oxa}$ zolone-induced allergic contact dermatitis in mice is mediated by leukotrienes, prostaglandins, histamine, inflammatory cytokines, and IgE and cellular infiltrate is associated with general predominance of mononuclear cells over neutrophils against which comparatively dexamethasone may have greater suppressive impact. ${ }^{27)}$ Moreover, unlike dexamethasone, the diterpenes action might have been restricted to the site of application. Since all mediator substances have not been analysed, it is difficult to explain from the present work, why the diterpenes action was declined with time. Possibly, these diterpenes are not as efficient as dexamethasone in suppressing the mediators formed during the time course of this chronic inflammatory model.

Many drug classes such as bradykinin antagonists, antihistaminergics and antiserotonergics, steroidal and nonsteroidal anti-inflammatory agents, and vanilloid antagonists like capsazepine and ruthenium red can modulate the ear edema response, depending on the nature of edematogen. ${ }^{28-30)}$ Also, plants and plant-originated substances have relevance in dermatology for both their adverse and beneficial effects on skin disorders and the skin in general. ${ }^{31)}$ Amongst the plant-derived natural products, the most effective groups with the inhibitory properties against contact dermatitis are the phenolics and terpenoids. Many of these compounds act by means of a non-specific mechanism (e.g. antioxidants), but may also act via specific mechanisms such as the inhibition of the mediators implicated in the immune response.

Previous studies established the anti-inflammatory activity of few diterpene compounds like suaveolol and methyl suaveolate from Hyptis suaveolens on Croton oil-induced dermatitis of the mouse ear, triptonide from Trypterigyum wilfordii against dermatitis induced by DNFB in the mouse skin, and andalusol from Sideritis foetens by mechanisms that involve $\mathrm{T}$ cell suppression, inhibition of cytokine production, and or inactivation of NF- $\kappa \mathrm{B} .{ }^{32-34)}$ The diterpene lactone AHAL has been reported to suppress the capsaicininduced ear edema, a valid model to screen compounds for potential antiallergic and local anti-inflammatory activities. However, it showed no obvious effect on paw edema induced by Compound $48 / 80$, histamine or serotonin but effectively decreased the vascular permeability increase induced by intraperitoneal acetic acid. ${ }^{16)}$ This suggests that AHAL exerts significant anti-inflammatory activity on topical edema induced by capsaicin through an action independent of mast cell stabilization or histamine- and serotonin-receptor antagonism. In the present study, CA and AHAL significantly suppressed the ear edema and the increased level of IFN- $\gamma$, a Th1 cytokine that activates various types of cells resulting in inflammatory events and the induction of skin hypertrophy due to an increase in keratinocyte proliferation. ${ }^{35,36)}$ In this context, a previous study described the antiproliferative activity of 12-acetoxy-hawtriwaic acid lactone on cell growth of human cell line, CCD922 normal skin fibroblasts. ${ }^{37)}$

In conclusion, we provided in vivo evidence to show that the diterpenes from Egletes viscosa are effective topical antiinflammatory agents in the experimental models of acute or chronic dermatitis and suggest that these may serve as lead compounds for developing drugs effective in skin inflammatory disorders like atopic or contact dermatitis and in psoriasis.

Acknowledgments The authors thank Antonia Dannyella Marques Ferreira for technical support. This study was supported by CNPq and CAPES, Brazil.

\section{REFERENCES}

1) Gates T., Aviat. Space Environ. Med., 78, 29-37 (2007).

2) Pónyai G., Temesvári E., Kárpáti S., Orv. Hetil., 148, $21-26$ (2007)

3) Kieć-Swierczyńska M., Krecisz B., Swierczyńska-Machura D., Australas. J. Dermatol., 48, 83-87 (2007).

4) Abma E. M., Blanken R., Deheide L. J., Neth. J. Med., 60, 148-150 (2002).

5) Abramovits W., Hung P., Tong K. B., Am. J. Clin. Dermatol., 7, $213-$ 
222 (2006).

6) Breuer K., Werfel T., Kapp A., Am. J. Clin. Dermatol., 6, 65-77 (2005).

7) Buys L. M., Am. Fam. Physician, 75, 523-528 (2007).

8) Vender R. B., Skin Therapy Lett., 7, 1-5 (2002).

9) Simpson E. L., Basco M., Hanifin J., Am. J. Contact Dermat., 14, $144-147$ (2003).

10) Nicolaou N., Johnston G. A., Contact Dermatitis, 51, 30-33 (2004).

11) Fernández M. A., Tornos M. P., García M. D., de las Heras B., Villar A. M., Sáenz M. T., J. Pharm. Pharmacol., 53, 867-872 (2001).

12) Ojo-Amaize E. A., Kapahi P., Kakkanaiah V. N., Takahashi T., Shalom-Barak T., Cottam H. B., Adesomoju A. A., Nchekwube E. J., Oyemade O. A., Karin M., Okogun J. I., Cell. Immunol., 209, 149157 (2001).

13) Stulzer H. K., Tagliari M. P., Zampirolo J. A., Cechinel-Filho V., Schlemper V., J. Ethnopharmacol., 108, 379-384 (2006).

14) Lima M. A., Silveira E. R., Marques M. S., Santos R. H., Gambardela M. T., Phytochemistry, 41, 217-223 (1996).

15) Guedes M. M., Cunha A. N., Silveira E. R., Rao V. S., Planta Med., 68, 1044-1046 (2002).

16) Melo C. M., Maia J. L., Cavalcante I. J., Lima M. A., Vieira G. A., Silveira E. R., Rao V. S., Santos F. A., Planta Med., 72, 584-589 (2006).

17) Zhang L., Tinkle S. S., J. Invest. Dermatol., 115, 168-176 (2000).

18) Murakawa M., Yamaoka K., Tanaka Y., Fukuda Y., Biochem. Pharmacol., 71, 1331-1336 (2006).

19) Recio M. C., Giner R. M., Máñez S., Rios J. L., Planta Med., 60, $231-234$ (1994)

20) Young J. M., De Young L. M., "Modern Methods of Pharmacology: Pharmacological Methods in the Control of Inflammation," ed. by Chang J. Y., Lewis A. J., Alan It Lies, Inc., New York, 1989.

21) Shin Y. W., Bae E. A., Kim S. S., Lee Y. C., Kim D. H., Int. Im- munopharmacol., 5, 1183-1191 (2005).

22) Fujii Y., Takeuchi H., Tanaka K., Sukuma S., Ohkubo Y., Mutoh S., Eur. J. Pharmacol., 456, 115-121 (2002).

23) Bradley P. P., Priebat D. A., Christensen R. D., Rothstein G., J. Invest Dermatol., 78, 206-209 (1982).

24) Kitagaki H., Ono N., Hayakawa K., Kitazawa T., Watanabe K., Shiohara T., J. Immunol., 159, 2484-2491 (1997).

25) Kimber I., Pichowski J. S., Basketter D. A., Dearman R. J., Toxicol. Lett., 106, 237-246 (1999).

26) Saulnier M., Huang S., Aguet M., Ryffel B., Toxicology, 102, 391312 (1995).

27) Ueda H., Yamazaki M., Biosci. Biotechnol. Biochem., 65, 1673-1675 (2001).

28) Mantione C. R., Rodriguez R., Br. J. Pharmacol., 99, 516-518 (1990).

29) Gabor M., Razga Z., Agents Actions, 36, 83-86 (1992).

30) Sterner O., Szallasi A., Trends Pharmacol. Sci., 20, 459-465 (1999).

31) Mantle D., Gok M. A., Lennard T. W., Adverse Drug React. Toxicol. Rev., 20, 89-103 (2001).

32) Grassi P., Urías Reyes T. S., Sosa S., Tubaro A., Hofer O., ZitterlEglseer K., Z. Naturforsch., 61, 165-170 (2006).

33) Pei R. J., Qi L. H., Liu X. J., Acta Pharmacol. Sin., 14, 238-242 (1993).

34) de las Heras B., Navarro A., Díaz-Guerra M. J., Bermejo P., Castrillo A., Boscá L., Villar A., Br. J. Pharmacol., 128, 605-612 (1999).

35) Tamura T., Matsubara M., Takada C., Hasegawa K., Suzuki K., Ohmori K., Karasawa A., Br. J. Dermatol., 151, 1133-1142 (2004).

36) Carroll J. M., Crompton T., Seery J. P., Watt F. M., J. Invest. Dermatol., 108, 412-422 (1997).

37) Pessoa C., Silveira E. R., Lemos T. L., Wetmore L. A., Moraes M. O., Leyva A., Phytother. Res., 14, 187-191 (2000). 